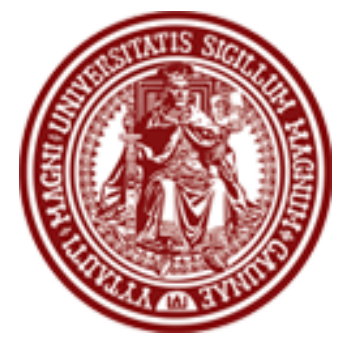

BALTIC JOURNAL OF LAW \& POLITICS

VOLUME 1 (2008)

ISSN 2029-0454

http://www.versita.com/science/law/bjlp

Cit.: Baltic Journal of Law \& Politics 1 (2008): 69-94

$10.2478 / v 10076-008-0005-1$

\title{
PRO-WESTERN ATTITUDES IN THE FIVE CENTRAL AND EAST EUROPEAN STATES: ELECTORAL BEHAVIOR
}

\author{
LIUDAS MAŽYLIS \\ Professor; Dr. \\ Vytautas Magnus University Faculty of Political Science and Diplomacy \\ (Lithuania) \\ Contact information \\ Address: Gedimino str. 44, LT-44240 Kaunas, Lithuania \\ Phone: 370-37-206709 \\ E-mail address: I.mazylis@pmdf.vdu.It
}

\section{ASTA SKIRMANTIENE்}

Doctoral Candidate

Vytautas Magnus University Faculty of Political Science and Diplomacy (Lithuania)

\section{Contact information}

Address: Gedimino str. 44, LT-44240 Kaunas, Lithuania

Phone: 370-37-206709

E-mail address: a.skirmantiene@pmdf.vdu.It

Received: November 11, 2008; reviews: 2; accepted: January 20, 2009.

\footnotetext{
ABSTRACT

This article examines electoral behavior in the post-communist countries of Central and Eastern Europe (Poland, the Baltic States and Ukraine). The main aim is to analyze electoral behavior in particular sub-national territories in order to discover differences and common trends in the countries examined. The article discusses interconnections between socio-economic, ethnic, and cultural characteristics of particular sub-national territories and the attitudes of their inhabitants expressed in voting results and opinion polls. The factor of post-World War II immigration (historic immigration) seems to still determine regional culture (including political preferences) in all the countries under consideration. The specific details of electoral behavior are analyzed using quantitative method. This method helps to examine the results of parliamentary and presidential elections and EU accession referenda of 2003. Correlations between independent and dependent variables repeated in a number of
} 
measurements show certain tendencies within each examined country. The totality of such tendencies demonstrates common trends of electoral behavior in post-communist space.

\section{KEYWORDS}

Post-communist electoral behavior, historic immigration, Baltic States, Poland, Ukraine

\section{ACKNOWLEDGEMENTS}

Previous versions of this paper were presented at the Midwest Political Science Association Annual Conference (Chicago, 2007), and, partly, at the Lithuanian Political Science Association Conference (Vilnius, 2006). We are indebted to the participants of these events for their comments and suggestions. We thank Gintaras Šumskas for research assistance. 


\section{INTRODUCTION}

Post-communist electoral studies can be based on different strategies. The dominant strand lies within the "transitional" approach. This leads most frequently to studies on "economic voting" ("rational choice" theories of political behavior) that explain the political consequences of democratization. Another strategy takes longterm cultural factors as its basis. As understood from an overview, ${ }^{1}$ the majority of publications are based on economic determinism. Typically, a variety of economic factors are to be tested as their influence on voting behavior (as a rule, leading to the conclusion that economic losses of transition are followed by voting for successor parties).

Investigation of first cases of democratic voting has revealed that other factors, such as ethnicity or independent "regional" variable, create a specific background for socio-economic motives. Efforts to conclude as to which possible "primary" factors determine the secondary "regional" ones are often used as a basis for further speculations. Therefore the regional differences tended to be interpreted as simply "cultural". Here the approach can be called "region based", especially as developed by scholars for studying the Ukraine. As Birch concludes, political attitudes in Ukraine vary from region to region according two interrelated factors: (1) their genesis in historical geo-political experience; (2) regional economic factors. ${ }^{2}$ A strong correlation between region and party support cannot be explained primarily by orientation toward the market or reforms, Kubicek argues. Support for parties in Ukraine runs along the ethnic/territorial/cultural cleavages that "are less negotiable and more "primordial" ". ${ }^{3}$ There appeared an assumption that with time those regional differences may recede, in association with the continuous state politics. ${ }^{4}$ However, it was evident that polarization in Ukraine does not diminish over time. ${ }^{5}$ In parallel with our investigation Kuzio says "in Ukraine "return to Europe" civic nationalism is not uniformly strong-it is weaker in eastern Ukraine, where the Orange Revolution found little support. ${ }^{\prime \prime}$ O'Loughlin says when reviewing literature on this problem "the regional patterns in political preferences come

\footnotetext{
1 Joshua Tucker, "The first decade of post-communist elections and voting: what have we studied, and how have we studied it?" Annu. Rev. Polit. Sci. Vol. 5, Issue 1 (2002): 294.

2 Sarah Birch, "Interpreting the Regional Effect in Ukrainian Politics," Europe-Asia Studies Vol. 52, No. 6 (2000): 1030 .

3 Paul Kubicek, "Regional Polarisation in Ukraine: Public Opinion, Voting and Legislative Behaviour," Europe-Asia Studies Vol. 52, No. 2 (March 2000): 288.

4 John O'Loughlin, "The Regional Factor in Contemporary Ukrainian Politics: Scale, Place, Space or Bogus Effect?" Post-Soviet Geography and Economics Vol. 42, No. 1 (2001): 1-33.

5 Paul Kubicek, supra note 3: 231.

6 Taras Kuzio, "Democratic Breakthroughs and Revolutions in Five Postcommunist Countries: Comparative Perspectives on the Fourth Wave," Demokratizatsiya Vol. 16, Issue 1 (Winter 2008): 100.
} 
through clearly in relation to Ukraine foreign policy with two broad (and perhaps rather simplistic) preferences apparent: "Slavic choice" and "European choice" ".7

Although troubles occurred, there were attempts to use quantitative methods for explaining this specific cultural factor. Because clear regional voting patterns persist, and because an ethnic component does clearly influence voting results, these "cultural" factors were supposed to connect somehow with either "territory" or "ethnicity". However, instead of ethnicity as the primary factor, Kubicek suggests the assumption that the western territories (of Ukraine) do possess a "sense of political community"; therefore, he argues, the east/west dichotomy exists because of the differing lengths of time under Russian/Soviet control. ${ }^{8}$ "Even simple measures of civic engagement also show a strong east-west gradient"; and "persistence of non-communitarian social capital in the post-independence Ukrainian west" does exist, O'Laughlin argues. ${ }^{9}$

Also, a separate branch of studies exists where cultural differences are explained within a "borderland" approach. There were a small number of attempts to look for reflection of different types of governing ("eastern" and "western") with voting patterns. Generations living on the land between the Baltic and Black Seas (including Estonia, Latvia, Lithuania, Poland, and Ukraine) experienced different types of governing throughout the ages. Breskiy proposes to take into consideration that division Europe into "East" and "West" is relatively new. ${ }^{10}$ Earlier, Latvia's election behavior was to be explained by a kind of "anti-East" (meaning, antiRussian, but also anti-Soviet) tendencies. ${ }^{11}$ Birch asserts that "historical experience" is one of the hypotheses ("regional economic conditions" is another such hypothesis) drawn from "political culture arguments". Western Ukrainians "perceive themselves Europeans" whereas eastern Ukrainians see themselves as "eastern Slavs". This implies a number of differences for geo-political value orientations and political behavior. A kind of cultural-deterministic framework was proposed for explaining why successor parties get 'above average levels' of electoral support. ${ }^{12}$

The orientation of CEE countries towards the EU was followed by new studies; ${ }^{13}$ accession referenda became a new object of comparative research. The

\footnotetext{
7 John O'Loughlin, supra note 4.

8 Paul Kubicek, supra note 3: 290.

9 John O'Loughlin, supra note 4.

10 Oleg Breskyi, "Geografiya Vostochnoy Evropy: prostranstvo Pogranich'ya," Perekryostki No 1-2 (2005): 179.

${ }_{11}$ Pal Kolsto and Boris Tsilevich, "Ethnic aspects of Parliamentary Elections in Latvia," East European Politics and Societies Vol. 11, No. 2 (Spring 1997): 376

12 Jacek Lubecki, "Echoes of Latifundism? Electoral Constituences of Successor Parties in PostCommunist Countries," East European Politics and Societies Vol. 18, No. 1 (2004): 10.

${ }^{13}$ Liudas Mažylis, Aušrinè Jurgelionytè, and Asta Skirmantienè, Nemeile Neeuropai (Non-Love to NonEurope) (Kaunas: VDU Leidykla, 2004): 8.
} 
series of referenda in eight Central and East European states in 2003 served as a new basis to turn back to the historical, cultural and geopolitical elements that influence voting in post-communist states. Although queries were made, those votes were called a "conclusive decision for the West"14. These referenda and citizens' attitudes on European integration were interpreted from the point of view of two types of theories: "cultural-ideological" and "rational (economic) choice". ${ }^{15}$ Furthermore, recent voting tendencies in the Baltic States, Poland and Ukraine from 2004 to 2007 show that votes for former communist parties declined in number. New cleavages appear, while the regional factor still remains.

At the end of the second post-communist voting decade those "boundary" territories become an interesting space for study because of the stabilizing geopolitical orientation of the region's states. Nowadays, a number of arguments emerge which recall the "cultural" approach mentioned above. The main one, regional difference as a factor in voting, emerged in the beginning of the transition and still remains after almost two decades. This leads to a search for explanations of societal cleavages that moves beyond just the economic factors. Lubecki was looking for explanations in the geographical lines of older times (though not within a "borderland" perspective - he included countries such as Germany and Russia): he concentrated on which governmental administrative space the territory belonged to. Differences of cultural substrate were explained as remaining throughout a number of generations. ${ }^{16}$

A multivariate statistical analysis is undertaken to test the effect of region. Aggregate level economic and demographic indicators and electoral data were used. Three sets of votes were compared in our analysis: (1) parliamentary; (2) presidential; (3) European accession referenda. Other variables do touch on ruralurban splits, agricultural and industrial labor patterns, and center-periphery distinctions. Statistical analysis was conducted using the SPSS for Windows 10 software package.

\section{HISTORIC REGIONS AND TODAY'S DIVISIONS}

To date, all five countries, being of different size, are administratively divided into regions that are equivalent neither in number nor size. Ukraine is divided into oblasts of the average size of inhabitants. Poland is divided into 16 wojewodztwa and 373 powiats, Lithuania into 60 savivaldybes with an average of 55,000

\footnotetext{
14 Geoffrey Pridham and Evald Mikkel, "Clinching the 'Return to Europe': The Referendums on EU Accession in Estonia and Latvia," West European Politics Vol. 27, No. 4 (September 2004 ): 745.

15 Piret Ehin, "Determinants of Public Support for EU Membership. Data from the Baltic Countries," European Journal of Political Research Vol. 40, No. 5 (August 2001): 36.

16 Jacek Lubecki, supra note 12: 26.
} 
inhabitants, Latvia into 5 zemes (electoral results available on this level) and 35 rajons, Estonia into 15 maakond and 2 cities. Historically, these territories belonged to three empires after the partition of the Polish-Lithuanian union in 1795. Between the two world wars part of Ukraine was under Soviet bolshevist rule, and the rest belonged to western countries.

\section{MAP: HISTORICAL AND CONTEMPORARY STATES BOUNDARIES ${ }^{17}$}

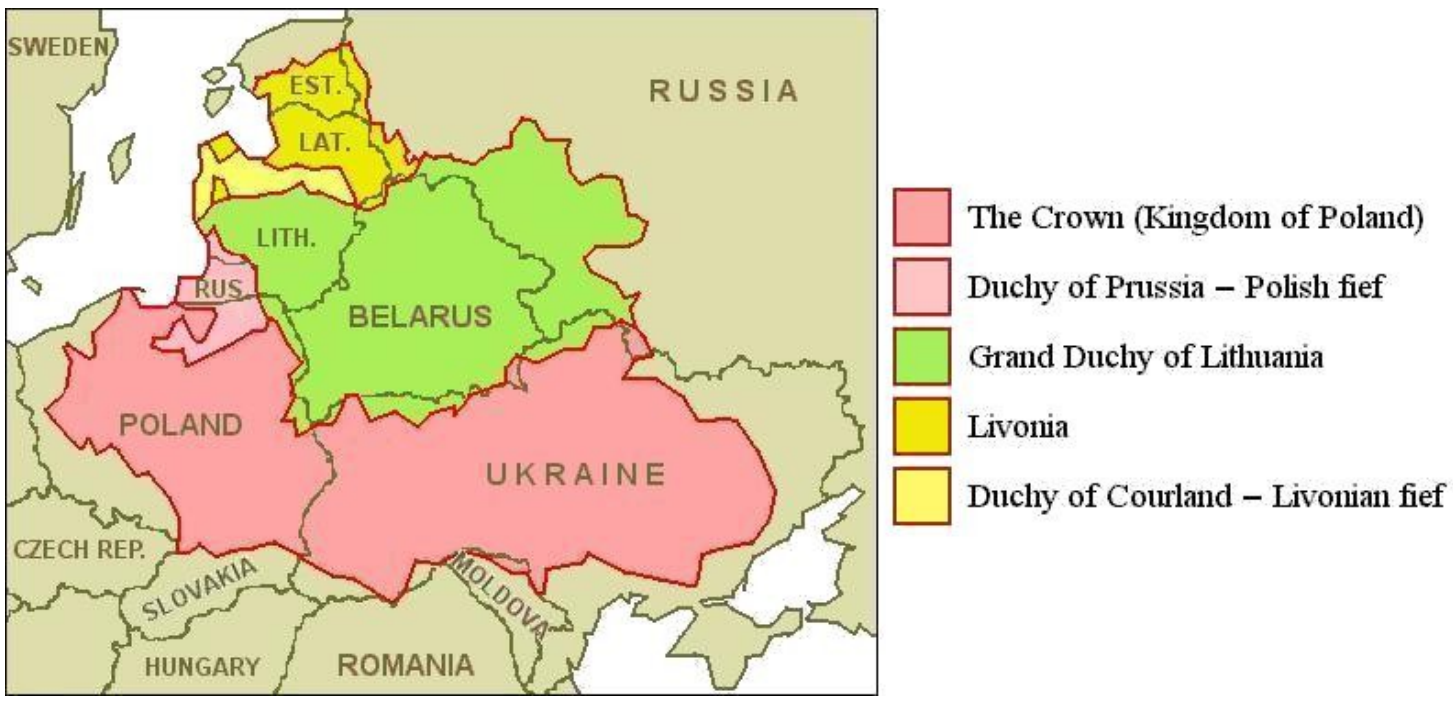

By dividing Poland into four historical regions Lubecki finds that the exGerman territories (Ziemie Odzyskane) vote more for successor left. His explanation of this result is that the poorer peasants came from other territories and lived relatively prosperously under communist rule. His conclusion was that "regions where communism built its own order on the pre-communist legacy of bitterness and poverty today show above-average levels of electoral support for the parties symbolically representing the communist system." ${ }^{18}$

Differences were the biggest between regions under the bolshevist regime and the western ones in Ukraine; "historical regions are especially important in the models for the right-of-center parties", "the leftist parties are less influenced by historical region". ${ }^{19}$ That may explain why region serves rather as the "side-effect" when exploiting economic determinist strategy. ${ }^{20}$

\footnotetext{
17 Map of former Polish-Lithuanian Commonwealth is taken from Wikimedia Commons, see at http://commons. wikimedia.org.

18 Jacek Lubecki, supra note 12: 42.

19 Sarah Birch, supra note 2: 1033.

20 Joshua Tucker, supra note 1: 295.
} 


\section{DO HISTORIC IMMIGRATION PATTERNS WORK?}

Looking for the universal factor to explain regional political culture differences, we turned to the typical one for these territories, migration. When attaching the variable of historic immigration to the appropriate periods in the past, we decided to take three periods into account: (1) Empires prior to WWI (three options): Russia, Germany, and Austria-Hungary; (2) interwar (two options): whether under bolshevist rule (Western Ukraine) or not; (3) after WWII: under bolshevist rule (all) but undergoing hard migration flows.

The variable of the composition of the region was composed from three elements: (1) Belonging to Empires (long time distance - weak echoes); (2) Bolshevization between wars ("hard" influence); (3) Postwar immigration ("hard" or "soft" influences, depending on where it was from). Our first attempt was to use categorical variables for testing the influence of the regional factor. The destruction of long-term enrooted communities by massive immigration was suspected to be the strongest during the communist period, especially in territories that never enjoyed a western type of governing. In turn, this destruction was weaker in territories within "westernized space".

We set three types of "macro" regions, characterized by: (1) Relative stable communities (if affected by migration though "local", within the same state); (2) Communities largely affected by immigration other but "western" states rather than immigration from "the East"; (3) Massive immigration flows from different ("East") space combined with ones also within the same state or from other states within "westernized" space.

Conceptually we draw differences, albeit slight ones, between the "experience of a western type of governing" and a "democratic experience", as well as between "immigrants from different government type space" and "ethnic Russians"; retrospective identity supported by today's perceived East-West dichotomy forms the system of attitudes and subsequent political behavior.

\section{THE PROBLEM OF WHO IS "MORE PRO-WESTERN" AMONG PARTIES} AND POLITICIANS

There is no doubt that the incumbent presidents of all five states (Yushchenko, Kaczynski, Adamkus, Vike-Freiberga, and Ilves) belong under the category of "pro-western", as determined by both analysts and public opinion. In addition, the presidents of all three Baltic States (two of them elected by parliaments, not direct vote) came home from western exile. 
About political parties: Nasha Ukraina and Tymoshenko's block in Ukraine have pro-western programs when compared with their counterparts. For Poland, Lithuania, Latvia, and Estonia, with only marginal pro-Eastern counterparts if any, possibly the whole spectrum of political parties may belong to "pro-western".

\section{OPERATIONALIZATION OF VARIABLES AND EMPIRICAL DATA}

We included in this study different types of elections (Ukraine - to the Rada and residential; Poland - to the Sejm and presidential: Lithuania - to the Seimas and presidential; also data from Latvia - and Estonia - 5 to the Riigikogu) from the more than twenty that exist in our database. A multivariate statistical analysis is undertaken to test the effect of region. Aggregate level economic and demographic indicators and electoral data were used.

The sample includes countries with different pasts, but all of which remain in transition from communist rule. They were both from and external to the Soviet Union. Parts of the states experienced existence under different regimes. Three sets of votes were compared in our analysis: (1) parliamentary (all five countries); (2) presidential (Lithuania, Poland, and Ukraine); (3) European accession referenda (Estonia, Latvia, Lithuania, and Poland). For the mixed Lithuanian legislative system, a proportional representation vote was analyzed. The second round of presidential elections was taken into account. Support for political parties served as dependent variables in this analysis. Other variables also touch on rural-urban splits, agricultural and industrial labor patterns, and center-periphery distinctions. Statistical analysis was conducted using the SPSS for Windows 10 software package.

Thus, the hypothesis to re-examine is: parts of post-communist space are distinguished by people's pro-Western attitudes, which are determined by persistent long-term cultural factors.

Our general approach was to use immigration as a kind of universal factor for all territories under consideration. We tended to measure immigration into particular regions during the period after WWII, then calculate the part played by immigrants from bolshevist territories between WWI and WWII. First, these countries differ in the nature of their immigration processes. The Baltic States underwent a similar process and can be compared with each other by the same variables, though with various nuances. There was another distinctly different type of migration in Poland: it was immigration from a similar space, not from bolshevist territories, which is essentially different, we insist. For the study of Ukraine, the problem of data collection occurred. When general figures about immigration are 
well known, those about regions could only be derived from sparse figures in Soviet census data. Another difficulty is that some of today's regions underwent different types of immigration influxes.

\section{CASE: UKRAINE}

There is a common perception that the historic fate of Ukraine is to be a permanently divided nation. This comes in the form of the Janus image ("two faces"), allusions to Goethe's Faust ("two souls"), etc. There is a lack of convincing explanations, still, on regional cleavages in Ukrainian politics. Explanations that they are "primordial", simply "geographic," ${ }^{21}$ are common. Indeed, according to electoral results, both before the "orange revolution" and after, regional division is evident. It has serious political consequences: long term internal institutional crisis continues, and memoranda on national unity do not work in reality.

In our independent variable, territory belonging to the Western type of administration, western oblasts (belonging to Austro-Hungary until World War I, then to Poland until 1939) underwent the longest impact, being under Soviet rule relatively shorter than others (1945-1991). Here, as well as in other countries under consideration, the main problem was how to evaluate immigration flows during the Soviet period. Territories such as, for example, Donetsk and Crimea, underwent the highest levels of immigration; thus, three types of territories of Ukraine were categorized as dummy variables (see Table 1 ).

HISTORICAL DETERMINANTS IN REGIONS OF TODAY'S UKRAINE ${ }^{22}$

Table 1

\begin{tabular}{|c|c|c|c|}
\hline Oblasti & $\begin{array}{c}\text { Belonged to Empire } \\
\text { before WWI }\end{array}$ & $\begin{array}{c}\text { Belonged to state } \\
\text { between Wars }\end{array}$ & Category \\
\hline Volyn' & Russia & Poland/ USSR & 1 \\
\hline Rivne & Russia & Poland/ USSR & 1 \\
\hline Zakatpatt'ya & Hungary & Czechoslovakia & 1 \\
\hline Chernivtsi & Austria & Romania & 1 \\
\hline Lviv & Austria & Poland & 1 \\
\hline Ternopil & Austria & Poland & 1 \\
\hline Ivano-Frankivsk & Austria & Poland & 1 \\
\hline
\end{tabular}

\footnotetext{
${ }^{21}$ Sarah Birch, "Electoral behaviour in Western Ukraine in national elections and referendums, 1989-91," Europe-Asia Studies Vol. 47, No. 7 (1995).

${ }^{22}$ Data is taken from the State Committee of Statistics, Ukraine, see at http://www.ukrstat.gov.ua, and Ukrainian population census 2001 website, see at http://www.ukrcensus.gov.ua/regions; Paul Kubicek, supra note 3: 275.
} 


\begin{tabular}{|c|c|c|c|}
\hline Kyiv city & Russia & USSR & 2 \\
\hline Kyiv oblast & Russia & USSR & 2 \\
\hline Viinyts'ya & Russia & USSR & 2 \\
\hline Zhytomir & Russia & USSR & 2 \\
\hline Kirovohrad & Russia & USSR & 2 \\
\hline Khmel'nyts'kyi & Russia & USSR & 2 \\
\hline Cherkasy & Russia & USSR & 2 \\
\hline Poltava & Russia & USSR & 3 \\
\hline Chernihiv & Russia & USSR & 3 \\
\hline Sumy & Russia & USSR & 3 \\
\hline Kharkiv & Russia & USSR & 3 \\
\hline Luhans'k & Russia & USSR & 3 \\
\hline Donets'k & Russia & USSR & 3 \\
\hline Dnipropetrovs'k & Russia & USSR & 3 \\
\hline Zaporizhzhya & Russia/ Ottoman & USSR & 3 \\
\hline Kherson & Russia/ Ottoman & USSR & 3 \\
\hline Mykolaiv & Russia/ Ottoman & USSR & 3 \\
\hline Odesa & Russia/ Ottoman & USSR & 3 \\
\hline Crimea & Russia/ Ottoman & USSR & 3 \\
\hline
\end{tabular}

Quantitatively, for Western Ukraine a 5\% average immigration (calculated as "from both other parts of Ukraine and Russia") is agreed on by experts. ${ }^{23}$

27 oblasts were analyzed. In two types of elections the dependent variable was support of Nasha Ukraina and Tymoshenko' block in Rada, and, correspondingly, support of Yushchenko or his rival Yanukovich in presidential elections (November and December, 2004). We also included a set of sociodemographic variables: urban-rural inhabitants, average income, unemployment, and ethnic groups.

Analysis shows that "stable cultural/geographic" variables can play a role when explaining electoral behavior in Ukraine. Immigration and territories belonging to a western-type administration, coded as the independent variable region, played a role in bolstering votes for Yushchenko in the 2004 December election (see Table 2$). R(R=0,508)$ and $P$ values $(p=0,000)$ show the significance of the model.

\footnotetext{
23 John O'Loughlin, supra note 4
} 
PRESIDENTIAL ELECTION IN UKRAINE ${ }^{24}$

Table 2

\begin{tabular}{|c|c|c|}
\hline \multicolumn{3}{|c|}{2004 December President Election } \\
\hline Variable & Beta & Sig. \\
\hline Region &,- 508 &, 000 \\
\hline Constant & $\mathrm{R}=, 508$ \\
\hline & $\mathrm{R}^{2}=, 258$ & \\
\hline & Sig. $=, 000$ & \\
&
\end{tabular}

The flow of immigration had a negative, statistically significant influence on votes for Yushchenko (beta $=-0,508$ ): a higher flow of immigration meant less votes for Yushchenko.

PARLIAMENT ELECTION IN UKRAINE ${ }^{25}$

Table 3

\begin{tabular}{|c|c|c|}
\hline \multicolumn{3}{|c|}{2006 Parliament Election } \\
\hline Variable & Beta & Sig. \\
\hline Region &,- 775 &, 007 \\
\hline Constant & &, 000 \\
\hline \multicolumn{2}{|c|}{$\mathrm{R}=, 775$} \\
$\mathrm{R}^{2}=, 601$ \\
\\
& Sig. $=, 007$ & \\
\hline
\end{tabular}

Table 3 shows that an interaction between the independent variable Region and the results of election was again evident. This time even higher coefficients $(R=0,775$, beta $=-0,775)$ denoted a significant relation between immigration and territories belonging to western-type administrations and the votes for Nasha Ukraina and Tymoshenko' block in 2006 parliamentary election. The same tendencies remain in the 2007 parliamentary election: $R=0,779$, beta $=-0,779$ (see Table 4).

\footnotetext{
${ }^{24}$ The data about the results of the elections is available at Central Election Commission of Ukraine, see at http://www.cvk.gov.ua; and the data of the economic and demographic indicators is available at State Committee of Statistics, Ukraine, see at http://www.ukrstat.gov.ua, and Ukrainian population census 2001 website, see at http://www.ukrcensus.gov.ua/regions.

${ }^{25}$ See explanation in the previous note.
} 
PARLIAMENT ELECTION IN UKRAINE ${ }^{26}$

Table 4

\begin{tabular}{|l|c|c|}
\hline \multicolumn{3}{|c|}{2007 Parliament elections } \\
\hline Variable & Beta & Sig. \\
\hline Region &,- 779 &, 000 \\
\hline Constan & $\mathrm{R}=, 779$ & \\
\hline & $\mathrm{R}^{2}=, 606$ & \\
& Sig. $=, 000$ & \\
&
\end{tabular}

Other variables: urban-rural inhabitants, average income, unemployment, ethnic groups. Multivariate regression analysis demonstrates the significance of these independent variables for the votes for Yushchenko in the 2004 December president election and Nasha Ukraina and Tymoshenko' block in the 2006 and 2007 parliamentary elections (see Table 5).

PRESIDENTIAL AND PARLIAMENTARY ELECTIONS IN UKRAINE ${ }^{27}$

Table 5

\begin{tabular}{|c|c|c|}
\hline \multicolumn{3}{|c|}{2004 December President Election } \\
\hline Variable & Beta & Sig. \\
\hline Rural population &, 630 &, 000 \\
\hline Ethnicity &,- 546 &, 154 \\
\hline Unemployment &, 223 &, 000 \\
\hline Income &, 862 &, 001 \\
\hline Constant & Multiple $\mathrm{R}=, 846$ \\
\hline & $\mathrm{R}^{2}=, 716$ & \\
\hline & Sig. $=, 000$ & Sig. \\
\hline Variable & $\mathbf{2 0 0 6}$ Parliament Election &, 021 \\
\hline Rural population & Beta &, 000 \\
\hline Ethnicity &, 327 &, 017 \\
\hline Unemployment &, 645 &, 011 \\
\hline Income &, 411 &, 194 \\
\hline Constant & & \\
\hline
\end{tabular}




\begin{tabular}{|c|c|c|}
\hline & $\begin{array}{l}\text { le } R=, \\
=, 725 \\
=, 000\end{array}$ & \\
\hline \multicolumn{3}{|c|}{2007 Parliament Election } \\
\hline Variable & Beta & Sig. \\
\hline Rural population & ,246 & ,073 \\
\hline Ethnicity &,- 489 &, 003 \\
\hline Unemployment & ,328 & ,033 \\
\hline Income & 307 &, 044 \\
\hline Constant & & ,954 \\
\hline \multicolumn{3}{|c|}{ Multiple $\mathrm{R}=, 888$} \\
\hline \multicolumn{3}{|c|}{$\mathrm{R}^{2}=, 789$} \\
\hline \multicolumn{3}{|c|}{ Sig. $=, 000$} \\
\hline
\end{tabular}

Standardized regression coefficients show that ethnic composition was significantly related to the votes for Yushchenko in the 2004 December President election and Nasha Ukraina and Tymoshenko' block in the 2006 and 2007 parliamentary elections. Rural population and average income were significantly related to the votes for Yushchenko in the 2004 December president election (beta (rural population) $=0,630 \mathrm{p}=0,000$; beta (income) $=0,862 \mathrm{p}=0,000$ ). Beta coefficients show that these independent variables were weaker in the 2006 Parliamentary election although the coefficients were quite statistically significant (beta (rural population) $=0,327 p=0,021$; beta (income) $=0,411 p=0,011$ ). On the other hand these variables are weaker in the 2007 parliamentary elections (beta (rural population) $=0,246 \mathrm{p}=0,073$; beta (income) $=0,307 \mathrm{p}=0,044$ ). However, analysis shows that "stable cultural/geographic" variables can play a role when explaining electoral behavior in Ukraine.

\section{CASE: POLAND}

From among four historic parts of Poland, Ziemie Odzyskane - belonging to Germany between WWI and WWII - underwent hard immigration from other parts of interwar Poland. Consequences such as socio-cultural differences are still felt in different spheres. ${ }^{28}$

Analysis on the levels both of 16 wojewodztwa and powiats was carried out. Socio-economic variables - urban-rural inhabitants (ratio of gminas below and

28 Jacek Lubecki, supra note 12: 54; Andrzej Sadowski, Spoleczne problemy miejscowosci polnocnowschodniej Polski w procesie transformacji (Societal problems of settlements of the South-Eastern Poland in a process of transformation), (Białystok: Wydawnictwo Uniwersytetu w Białymstoku, 2001). 
above 10 thousand inhabitants), average salary, GDP per capita - were included (see Table 6).

HISTORICAL DETERMINANTS IN REGIONS OF TODAY'S POLAND ${ }^{29}$

Table 6

\begin{tabular}{|c|c|c|c|}
\hline Wojewodztwo & $\begin{array}{c}\text { Belonged to Empire } \\
\text { before WWI }\end{array}$ & $\begin{array}{c}\text { Belonged to state } \\
\text { between Wars }\end{array}$ & Category \\
\hline Warminsko-Mazurskie & Germany & Germany & $4 ; 3$ \\
\hline Zachodnio-Pomorskie & Germany & Germany & 4 \\
\hline Lubuskie & Germany & Germany & 4 \\
\hline Dolnoslaskie & Germany & Germany & 4 \\
\hline Opolskie & Austria & & 4 \\
\hline Slaskie & Austria & & $1 ; 2 ; 4$ \\
\hline Malopolskie & Austria & Poland & $1 ; 2$ \\
\hline Podkarpackie & Austria & Poland & 1 \\
\hline Pomorskie & Germany & Poland & $2 ; 3$ \\
\hline Kujawsko-Pomorskie & Russia & Poland & $2 ; 3 ; 4$ \\
\hline Wielkopolskie & Russia & Poland & 2 \\
\hline Lodzkie & Russia & Poland & 2 \\
\hline Mazowieckie & Russia & Poland & 2 \\
\hline Swietokrzyskie & Russia & Poland & 2 \\
\hline Podlaskie & Russia & Poland & 2 \\
\hline Lubelskie & Russia & & \\
\hline & & & $2 ; 4$ \\
\hline
\end{tabular}

16 wojewodztwa and 373 powiats were analyzed in total. Analysis suggests that socio-cultural differences of the powiats, coded as the independent variable Region, played a negative role in bolstering votes for Kaczynski in the 2005 President election in Poland (see Table 7).

${ }^{29}$ Data is taken from the Central Statistical Office, Poland, see at http://www.stat.gov.pl; Przemyslaw Sleszynski, "Uwarunkowania zroznicowan przestrzennych wynikow egzaminu gimnazjalnego w 2002 r." (Spatial determination of differences in the results of gymnasium exams of 2002), http://www.igipz.pan.pl/miasto/zbiory/egz_gimn_2002_igipz_pan.pdf. 
PRESIDENT ELECTION IN POLAND ${ }^{30}$

Table 7

\begin{tabular}{|c|c|c|}
\hline \multicolumn{3}{|c|}{ 2005 President Election } \\
\hline Variable & Beta & Sig. \\
\hline Region &,- 677 &, 000 \\
\hline Constant & $\mathrm{R}=, 677$ & \\
\hline \multicolumn{3}{|c|}{$\mathrm{R}^{2}=, 458$} \\
\\
& Sig. $=, 000$ & \\
&
\end{tabular}

P-value of zero to three decimal places shows the significance of the model and R-squared indicates that approximately $46 \%$ of the variability of votes for Kaczynski is accounted for by the model. Higher historic immigration has a negative, statistically significant influence on votes for Kaczynski (beta=-0,677). On the other hand, an interaction effect between Region and votes for Tusk in the 2005 President election has positive statistically significant coefficients that show that higher historic immigration has a positive influence on votes for Tusk $(R=0,677$ $p=0,000$ beta $=0,677)$. There is a statistically significant though weaker relationship between historic immigration and votes for Prawo $i$ Sprawiedliwosc in the 2005 parliament Election (see Table 8).

PARLIAMENT ELECTION IN POLAND ${ }^{31}$

Table 8

\begin{tabular}{|l|c|c|}
\hline \multicolumn{3}{|c|}{ 2005 Parliament Election } \\
\hline Variable & Beta & Sig. \\
\hline Region &,- 442 &, 000 \\
\hline Constant & $\mathrm{R}=, 442$ & \\
\hline & $\mathrm{R}^{2}=, 195$ & \\
& Sig. $=, 000$ & \\
&
\end{tabular}

The similarity to votes for Kaczynski in the direction of the coefficients (beta=0,442 ) indicates that greater historic immigration in the region has a negative influence on the votes for Prawo iI Sprawiedliwosc. The table shows that an

\footnotetext{
30 The data about the results of the elections is available at National Electoral Commission, Poland, see at http://www.pkw.gov.pl; and the data of the economic and demographic indicators is available at Central Statistical Office, Poland, see at http://www.stat.gov.pl.

${ }^{31}$ See explanation in the previous note.
} 
interaction effect is weaker than in the case of the presidential election, but still significant ( $p=0,000 R=0,442)$.

Multivariate analysis shows that not one of the socioeconomic variables is significantly related to the votes for Kaczynski during the 2005 president election $(p=0,135)$ and to the votes for Prawo i Sprawiedliwosc during the 2005 parliament election $(p=0,546)$.

\section{CASE: LITHUANIA}

Today's Lithuanian territory belonged to the Russian Empire from 1795 (the Grand Duchy of Lithuania included parts of all the five states examined in this article from $15^{\text {th }}$ to the 17 th century) until 1914. The exception is Klaipeda district: it belonged to Germany until WWI (earlier to Prussia). After WWI Lithuania regained independence only to be occupied again between 1945 and 1990, this time by the Soviets. Thus, the whole territory belonged to "Western space" between WWI and II, though parts of it underwent "hard" post-war immigration. Due to historical circumstances, this post-war immigration was not as great as in Latvia (Estonia was in-between) (Misiunas, Taageperaa, 1983). Nevertheless, compact living of Soviet-time immigrants still exists in Visaginas. The Klaipeda region underwent mixed (both "hard" and "soft") immigration when German troops were fully removed in 1945 . The same can be said about the Šalčininkai and Vilnius regions where Poles repatriated after WWII by subsequent immigration from different parts of Belarus (which belonged, in part, to Poland and the USSR during the interwar period). Therefore we suggest two types of "historic immigration" variables, "hard" (from the Eastern space) and "local".

In total 60 savivaldybès were analyzed. Socioeconomic variables: urban-rural inhabitants, average income, unemployment, ethnic groups (see Table 9). 
HISTORICAL REGIONAL FACTORS: LITHUANIA ${ }^{32}$

Table 9

\begin{tabular}{|c|c|c|c|c|}
\hline Savivaldybes & $\begin{array}{c}\text { Belonged to } \\
\text { Empire before } \\
\text { WWI }\end{array}$ & $\begin{array}{c}\text { Belonged to } \\
\text { State between } \\
\text { Wars }\end{array}$ & $\begin{array}{c}\text { Immigration } \\
\text { from East } \\
\text { between } \\
\text { WWII and } \\
1959 \text { among } \\
\text { all } \\
\text { inhabitants, } \\
\text { per cent }\end{array}$ & $\begin{array}{c}\text { Local } \\
\text { immigration } \\
\text { between } \\
\text { WWII and } \\
1959 \text { among } \\
\text { all } \\
\text { inhabitants, } \\
\text { per cent }\end{array}$ \\
\hline Vilnius & Russia & Poland & 60 & 30 \\
\hline Vilnius region & Russia & Poland & 40 & 10 \\
\hline Druskininkai & Russia & Poland & 40 & 40 \\
\hline Salcininkai & Russia & Poland & 30 & 10 \\
\hline Ignalina & Russia & Poland & 10 & 5 \\
\hline Svencionys & Russia & Poland & 15 & 5 \\
\hline Trakai & Russia & Poland & 20 & 15 \\
\hline Varena & Russia & Poland & 10 & 5 \\
\hline Visaginas* & Russia & Poland & 90 & 10 \\
\hline Klaipeda & Germany & Germany & 40 & 60 \\
\hline $\begin{array}{c}\text { Klaipeda } \\
\text { region }\end{array}$ & Germany & Germany & 5 & 75 \\
\hline Silute & Germany & Germany & 5 & 75 \\
\hline Pagegiai & Germany & Germany & 5 & 75 \\
\hline Neringa & Germany & Germany & 35 & 55 \\
\hline $\begin{array}{l}\text { Other } 46 \\
\text { regions }\end{array}$ & Russia & Lithuania & 0 & 0 \\
\hline
\end{tabular}

* Main influx of immigrants in the 1980s.

Immigration from the East and local immigration are chosen as predictors looking for effects on election results. Multivariate analysis suggests that these independent variables have an interaction effect on votes for Valdas Adamkus in the 1997 and 2004 presidential election. In the 2002 presidential election the

32 Values calculated by authors deriving from data in these sources: Centralinis statistikos biuras, Lietuvos statistikos metraštis $1939 \mathrm{~m} .12 \mathrm{t}$. (Statistical yearbook of Lithuania, 1939, vol. 12), (Kaunas, 1940), p. 13-14; Valstybinè statistikos leidykla, Lietuvos skyrius, 1959 metu visasajunginio gyventoju surašymo duomenys (Lietuvos TSR miestai ir rajonai) (Data of All-Union Census of 1959 (Towns and Regions of Lithuanian SSR)), (Vilnius, 1962), p. 102-109; Statistikos departamentas prie Lietuvos Respublikos Vyriausybès, 1989 metu gyventoju surašymo duomenys (Data of Census of 1989), (Vilnius, 1991), p. 14-19. 
relationships between the two types of historic immigration and votes for Valdas Adamkus are not significant $(R=0,351)$. There are even less significant relationships between immigration factors and party results - Tèvynes Sajunga in the 1996 $(R=0,267 p=0,122), 2000 \quad(R=0,176 p=0,408)$, and $2004 \quad(R=0,234 p=0,202)$ parliamentary elections.

Table 10 shows that immigration from the East and local immigration have a statistically significant $(R=0,636 p=0,000)$ but opposite effect on votes for Valdas Adamkus. Standardized regression coefficients show that greater local immigration increase (beta $=0,476$ ) and immigration from the East decreased (beta $=-0,650$ ) votes number for Valdas Adamkus in the 1997 president election.

PRESIDENTIAL ELECTION IN LITHUANIA ${ }^{33}$

Table 10

\begin{tabular}{|c|c|c|}
\hline \multicolumn{3}{|c|}{1997 President Election } \\
\hline Variable & Beta & Sig. \\
\hline Soft Imigration &, 476 &, 000 \\
\hline Hard Imigrationt &,- 650 &, 000 \\
\hline Constant & $\mathrm{R}=, 636$ & \\
\hline \multicolumn{2}{|c|}{$\mathrm{R}^{2}=, 400$} \\
\\
& Sig. $=, 000$ & \\
\hline
\end{tabular}

There is similar direction of the coefficients in the 2004 president election (see Table 11).

PRESIDENTIAL ELECTION IN LITHUANIA ${ }^{34}$

Table 11

\begin{tabular}{|c|c|c|}
\hline \multicolumn{3}{|c|}{ 2004 President Election } \\
\hline Variable & Beta & Sig. \\
\hline Soft Imigration &, 301 &, 019 \\
\hline Hard Imigrationt &,- 543 &, 000 \\
\hline Constant & &, 000 \\
\hline
\end{tabular}

${ }^{33}$ The data about the results of the elections is available at Central Electoral Commission of the Republic of Lithuania, see at http://www.vrk.It/en/; and the data of the economic and demographic indicators is available at Department of Statistics to the Government of the Republic of Lithuania, see at http://www.stat.gov.It/en/.

${ }^{34}$ See explanation in the previous note. 


$$
\begin{gathered}
R=, 506 \\
R^{2}=, 256 \\
\text { Sig. }=, 000
\end{gathered}
$$

In 2004 the relationship between historic immigration factors and votes for Valdas Adamkus was weaker than in 1997 but still statistically significant $(R=0,506$ $p=0,000)$. Standardized regression coefficients like in 1997 have opposite directions but this time it is smaller (beta $=0,301$ and $=-0,543$ respectively).

Multivariate analysis shows a statistically significant relationship between socioeconomic variables and the results of the presidential and parliamentary elections. The R-value is not less than 0,547 (2000 parliamentary election) and the p-value more than 0,001 (also 2000 parliamentary election) in every election. The most significant independent variable, which has the greatest effect on votes for Adamkus in presidential elections and for Tévynès Sajunga in the parliament election, is the ethnic composition of the region. Negative coefficients show that more ethnic minorities in the region mean fewer votes for Valdas Adamkus or Tèvynès Sajunga. Another significant variable is unemployment in 1997 (beta=0,218 $p=0,032$ ), 2000 (beta=0,392 $p=0,005$ ), 2004 (beta=0,439 $p=0,001$ ), 2002 (beta $=0,482 p=0,000$ ), 2004 (beta=0,284 $p=0,012$ ) presidential and parliament elections. Income and rural inhabitants are not statistically significant variables in the elections.

\section{CASE: LATVIA}

After the Russian Empire Latvia created its own state and existed independently between 1919 and 1940. It was occupied by the Soviets between 1945 and 1991. Thus, it belonged to Western space between WWI and II. During the Soviet occupation, massive amounts of immigrants flowed in. The capital city Riga, the sea ports Liepaja and Ventspils, and especially Daugavpils as well as other parts of Latgale underwent the most massive influx (Misiunas, Taageperaa, 1983; Latvian Statistics Bureau). Constant immigrant flow was typical for these regions during the subsequent decades after WWII. We take into consideration "macro"regions of Latvia, marking the highest values of immigration for two of them, Riga and Latgale.

In Latvia "the boundary between the Russians and the "natives" is not so sharply drawn as is in Estonia. Even non-citizen Russians are more deeply immersed into a Latvian environment than are the average Russians in Estonian 
society. ${ }^{\prime 35}$ Thus, though not all immigrants do possess voting rights already, one can expect the indirect effect of "historic immigration".

In total 33 rajoni belonging to 5 historical regions plus Riga and Riga's region were analyzed. Other variables: urban-rural inhabitants, average income, unemployment, and ethnic groups (see Table 12).

HISTORICAL DETERMINANTS IN REGIONS OF TODAY'S LATVIA ${ }^{36}$

Table 12

\begin{tabular}{|c|c|c|c|}
\hline Zemes & $\begin{array}{c}\text { Belonged to } \\
\text { Empire before } \\
\text { WWI }\end{array}$ & $\begin{array}{c}\text { Belonged to state } \\
\text { between Wars }\end{array}$ & $\begin{array}{c}\text { Immigration from } \\
\text { East , category }\end{array}$ \\
\hline Riga & Russia & Latvia & 3 \\
\hline Rigas region & Russia & Latvia & 1 \\
\hline Vidzeme & Russia & Latvia & 1 \\
\hline Kurzeme & Russia & Latvia & 1 \\
\hline Zemgale & Russia & Latvia & 3 \\
\hline Latgale & Russia & Latvia & \\
\hline
\end{tabular}

A 2003 EU referendum shows the anti-western positions of the regions with large Russians population (see Table 13).

EU REFERENDUM IN LATVIA ${ }^{37}$

Table 13

\begin{tabular}{|c|c|c|}
\hline \multicolumn{3}{|c|}{ EU Referendum } \\
\hline Variable & Beta & Sig. \\
\hline Russians &,- 789 &, 045 \\
\hline Latvians &,- 009 &, 981 \\
\hline Constant & $\mathrm{R}=, 780$ & \\
\hline & $\mathrm{R}^{2}=, 609$ & \\
\hline & Sig. $=, 000$ & \\
\hline
\end{tabular}

P-value of zero to three decimal places shows the significance of the model and R-squared indicates that approximately $61 \%$ of the variability of votes for

35 Pal Kolsto and Boris Tsilevich, supra note 11: 384.

${ }^{36}$ Data is taken from the Latvian Statistics Bureau, see at http://data.csb.Iv; Romuald Misiunas and Rein Taagepera, The Baltic States: Years of Dependence 1940-1980 (University of California Press, 1983).

37 The data about the results of the elections is available at Central Election Commission of Latvia, see at http://web.cvk.Iv/pub/public/; and the data of the economic and demographic indicators is available at Latvian Statistics Bureau, see at http://www.csb.gov.lv/?lng=en. 
membership in the EU is accounted for by the model. Higher number of Russians in the region have a negative, statistically significant influence on votes for Latvia's membership in EU (beta=-0,789). The other independent variable Latvians has no statistically significant effect on votes for membership in the EU (beta=-0,009 $\mathrm{p}=0,981$ ).

Multivariate analysis shows that the relationship is statistically significant in all parliament elections. The least R-value is 0,631 (2002 parliament election) and the highest $p$-value is 0,005 (also parliament election). The most significant independent variable, which has the greatest effect on votes for Tevzemei un Brivibai in parliament election, is the ethnic composition of the region. It has a negative effect on the votes for Tevzemei un Brivibai. Another statistically significant variable is income. It has a positive effect on votes for Tevzemei un Brivibai.

\section{CASE: ESTONIA}

Historical regionalization in Estonia is quite similar to Latvia. Differences are more quantitative rather than qualitative (the immigration numbers were smaller). One important difference is that the two major communities of Estonian speakers and Russian speakers are less culturally interpenetrated as in Latvia. Three regions were the most affected by hard immigration: Ida-Virumaa (shale mines), the capital city Tallinn, and Harjumaa (region surrounding Tallinn) (see Table 14).

HISTORICAL DETERMINANTS IN REGIONS OF TODAY'S ESTONIA ${ }^{38}$

Table 14

\begin{tabular}{|c|c|c|c|}
\hline Maakond & $\begin{array}{c}\text { Belonged to } \\
\text { Empire before } \\
\text { WWI }\end{array}$ & $\begin{array}{c}\text { Belonged to state } \\
\text { between Wars }\end{array}$ & $\begin{array}{c}\text { Immigration from } \\
\text { East, category }\end{array}$ \\
\hline Tallinn & Russia & Estonia & 3 \\
\hline Ida-Viru & Russia & Estonia & 3 \\
\hline Harju & Russia & Estonia & 2 \\
\hline Other 12 regions & Russia & Estonia & 1 \\
\hline
\end{tabular}

In total 17 regions (maakond) were analyzed. Socioeconomic variables: urban-rural inhabitants, average income, unemployment, ethnic groups, and religions. Analysis shows that historic immigration has a significant effect on votes

38 Data is taken from the Estonia Statistical Database, see at http://pub.stat.ee/pxweb.2001/dialog/statfileri.asp; Romuald Misiunas and Rein Taagepera, supra note 36. 
in parliamentary elections. The least $p$-value is 0,134 and the highest R-value is 0,379 for Isamaa in the 1995 election.

In Estonia, up to the date of the EU accession referendum, there was an assumption that "Russia will never be back". The disappearance of "fears of Russia" is explained by changing attitudes of Estonians towards Europe, introducing the new term, "reactive identity", connected with "new geo-political realities" as modern Estonians tend them to perceive them (Vetik, Nimmerfelft, Taru, 2006).

Analysis shows that neither immigration from the East nor local immigration has a significant effect on votes in parliamentary elections. The least p-value is 0,134 and the highest R-value is 0,379 in 1995 election for Isamaa. There is no significant relationship in 2007 elections: $R=0,063 p=0,811$. Other variables: urban-rural inhabitants, average income, unemployment, ethnic groups, and religions. Multivariate analysis also shows that none of the socioeconomic variables had a significant effect tested on the level of 17 regions.

\section{PRO-WESTERN BUT NOT PRO-EUROPEAN?}

In terms of "cultural-ideological" theories, European integration referenda in Central Eastern Europe in 2003 had to most significantly influence the geopolitical decision-making of the nations. However, the results were to be interpreted also within a "socio-economic" approach (leading in general to evidence that these individuals who benefited from economic transition are more supportive of Europe). The research reveals that electoral behavior is predicted by the Russian-speaking citizens' percentage (especially in Lithuania and Latvia) in correlation with social and economic factors. In Latgala, which experienced historical immigration and which coincides with today's border migration factors and socio-economic divide, the result was that the majority voted against membership in the European Union.

Different patterns were demonstrated in Estonia and Poland, correspondingly. Here, besides the dominant explanation of euro-optimism ("choosing West instead of East"), contradictory "cultural" variables should be taken into account (Euroscepticism in Poland because of being "more Christian than the rest of Europe ${ }^{\prime 39}$ ), as well as party ideology factors ${ }^{40}$. "Reactive identity" became an important pattern in Estonia, though in this case not as a response to the "fear of the East". ${ }^{41}$ Opinion

\footnotetext{
39 Aleks Szczerbiak, "History Trumps Government Unpopularity: The June 2003 EU Accession Referendum," West Euopean Politics Vol. 27, Issue 4 (September 2004): 681.

40 Radoslaw Markowski and Joshua Tucker, "Pocketbooks, politics, and parties: the 2003 Polish referendum on EU membership," Electoral Studies Vol. 24, Issue 3 (September 2005): 423.

41 Raivo Vetik, Gerli Nimmerfelft, and Marti Taru, "Reactive Identity versus EU Integration," Journal of Common Market Studies Vol. 44, No. 5 (December 2006): 1090.
} 
polls do show that Euro-scepticism has remarkably decreased since $2003 .{ }^{42}$ It all goes to show that "NO" votes in European integration referenda do not really confirm a mere "anti-European" vote as a contradictory action in the transition from Eastern to Western space.

\section{CONCLUSIONS}

Explanatory strategy, drawn from political culture factors such as historical circumstance but which still maintain influence on modern political behavior, was re-examined in five post-communist countries (Ukraine, Poland, Lithuania, Latvia, and Estonia).

Regional factors, besides socio-economic variables, still persist, though with a differing importance in each country under consideration. The regional variable keeps its independent effect in a number of recent cases of voting such as parliamentary and presidential elections in Ukraine, Poland, and Lithuania; thus, it persists even after the nearly two decades since the beginning of the postcommunist transitions. Examining regional voting patterns in the other two Baltic States, Latvia and Estonia, the effects are less evident.

When trying to explain the persistence of regional factors and the enrooted nature of regional voting differences throughout the passage of time in particular countries, we suggest (re-)considering the historical immigration factor. We assume that the consequences of migration after the Second World War still determine regional culture (including political preferences) in all the countries under consideration as being and remaining borderlands between two spaces that can be called "Eastern" and "Western". The differences between Western and contemporary Russian governing culture as perceived by the current populations of the countries examined here seem to be a factor in supporting the maintenance of regional divisions. From among all five countries, Lithuania looks like the most convenient model here, as historic immigration flows from Eastern space into particular Lithuanian regions can be easily differentiated. Then, because of having granted full citizen rights to immigrants, these differences of voting may be reasonably explained.

In Estonia and Latvia, one can hardly expect to see the direct influence of historic immigration on voting behaviour, solely for the simple reason that in these countries immigrants only gradually receive(d) their voting rights in parliamentary elections.

\footnotetext{
42 Eurobarometer 66: Public Opinion in the European Union. (2006) // http://ec.europa.eu/public_opinion/archives/eb/eb66/eb66_highlights_en.pdf.
} 
In Ukraine, analysis based on the three differently "Westernized" macroregions supports findings already known: regional voting for two nationaldemocratic parties still maintains its pattern.

For Poland, a different type of historic migration was the case. The massive influx of people to Ziemie Odzyskane from other parts of interwar Poland led to different types of communist economic order and subsequent regional cultural differences. This regional cleavage is more evident in recent presidential election voting when compared with voting for parliamentary parties.

All in all, the historic immigration factor seems to remain important in the determination of voting behavior. This further suggests how voting patterns, when caused by immigration, can be connected with pro-western attitudes. If historic immigration still remains important for maintaining two different types of communities, "destroyed" and "enrooted", this can become a factor for supporting one or another party. Parties called "national democratic"/"national conservative" maintain their support in territories of "stable communities" rather than those "destroyed" by historic immigration flows.

The EU accession referenda of 2003 should be treated quite separately. They differ both in terms of the motivation of voters and campaign specifics, and, to some extent, differ regionally in the patterns of the results. They cannot be interpreted as solely "clinching a return to the West". Regional patterns are present in these campaigns but with a different meaning.

\section{BIBLIOGRAPHY}

1. Birch, Sarah. "Electoral behaviour in Western Ukraine in national elections and referendums, 1989-91." Europe-Asia Studies Vol. 47, No. 7 (1995): 11451175.

2. Birch, Sarah. "Interpreting the Regional Effect in Ukrainian Politics." EuropeAsia Studies Vol. 52, No. 6 (2000): 1017-1041.

DOI: $10.1080 / 09668130050143815$.

3. Breskyi, Oleg. "Geografiya Vostochnoy Evropy: prostranstvo Pogranich'ya" (Geography of the Eastern Europe: Frontier space). Perekryostki No. 1-2 (2005): 168-186.

4. Centralinis statistikos biuras. Lietuvos statistikos metraštis $1939 \mathrm{~m} .12 \mathrm{t}$. (Statistical yearbook of Lithuania, 1939, vol. 12). Kaunas, 1940.

5. Ehin, Piret. "Determinants of Public Support for EU Membership. Data from the Baltic Countries." European Journal of Political Research Vol. 40, No. 5 (August 2001): 31-56. 
DOI: $10.1111 / 1475-6765.00588$.

6. Eurobarometer 66: Public Opinion in the European Union. (2006) // http://ec.europa.eu/public_opinion/archives/eb/eb66/eb66_highlights_en.pdf.

7. Kolsto, Pal, and Boris Tsilevich. "Ethnic aspects of Parliamentary Elections in Latvia." East European Politics and Societies Vol. 11, No. 2 (Spring 1997): 366-391.

8. Kubicek Paul. "Regional Polarisation in Ukraine: Public Opinion, Voting and Legislative Behaviour." Europe-Asia Studies Vol. 52, No. 2 (March 2000): 273294.

DOI: $10.1080 / 09668130050006790$.

9. Kuzio, Taras. "Democratic Breakthroughs and Revolutions in Five Postcommunist Countries: Comparative Perspectives on the Fourth Wave." Demokratizatsiya Vol. 16, Issue 1 (Winter 2008): 97-109.

10. Lubecki, Jacek. "Echoes of Latifundism? Electoral Constituences of Successor Parties in Post-Communist Countries." East European Politics and Societies Vol. 18 , No. 1 (2004): 10-44.

DOI: $10.1177 / 0888325403258286$.

11. Markowski, Radoslaw, and Joshua Tucker. "Pocketbooks, politics, and parties: the 2003 Polish referendum on EU membership." Electoral Studies Vol. 24, Issue 3 (September 2005): 409-433.

DOI: $10.1016 /$ j.electstud.2004.10.011.

12. Mažylis, Liudas, Aušrinè Jurgelionytè, and Asta Skirmantienè. Nemeilè Neeuropai (Non-Love to Non-Europe). Kaunas: VDU Leidykla, 2004.

13. Misiunas, Romuald, and Rein Taagepera. The Baltic States: Years of Dependence 1940-1980. University of California Press, 1983.

14. O'Loughlin, John. "The Regional Factor in Contemporary Ukrainian Politics: Scale, Place, Space or Bogus Effect?" Post-Soviet Geography and Economics Vol. 42, No. 1 (2001): 1-33.

15. Pridham, Geoffrey, and Evald Mikkel. "Clinching the 'Return to Europe': The Referendums on EU Accession in Estonia and Latvia." West European Politics Vol. 27, No. 4 (September 2004): 716-748.

DOI: $10.1080 / 0140238042000249958$.

16. Sadowski, Andrzej. Spoleczne problemy miejscowosci polnocno-wschodniej Polski w procesie transformacji (Societal problems of settlements of the South-Eastern Poland in a process of transformation). Białystok: Wydawnictwo Uniwersytetu w Białymstoku, 2001.

17. Sleszynski, Przemyslaw. "Uwarunkowania zroznicowan przestrzennych wynikow egzaminu gimnazjalnego w 2002 r." (Spatial determination of 
differences in the results of gymnasium exams of 2002). // http://www.igipz.pan.pl/miasto/zbiory/egz_gimn_2002_igipz_pan.pdf.

18. Statistikos departamentas prie Lietuvos Respublikos Vyriausybès. 1989 metu gyventoju surašymo duomenys (Data of Census of 1989). Vilnius, 1991.

19. Szczerbiak, Aleks. "History Trumps Government Unpopularity: The June 2003 EU Accession Referendum." West European Politics Vol. 27, Issue 4 (September 2004): 671-690.

DOI: $10.1080 / 0140238042000249876$.

20. Tucker, Joshua. "The first decade of post-communist elections and voting: what have we studied, and how have we studied it?" Annu. Rev. Polit. Sci. Vol. 5, Issue 1 (2002): 271-304.

21. Valstybinè statistikos leidykla, Lietuvos skyrius. 1959 metu visasajunginio gyventoju surašymo duomenys (Lietuvos TSR miestai ir rajonai) (Data of AllUnion Census of 1959 (Towns and Regions of Lithuanian SSR)). Vilnius, 1962.

22. Vetik, Raivo, Gerli Nimmerfelft, and Marti Taru. "Reactive Identity versus EU Integration." Journal of Common Market Studies Vol. 44, No. 5 (December 2006): 1079-1102.

DOI: $10.1111 / j .1468-5965.2006 .00674 . x$. 